\title{
Anaerobic Co-Digestion of Cow Manure and Palm Oil Mill Effluent (POME): Assessment of Methane Production and Biodegradation Efficiency
}

\author{
Darwin*, Novi Diana, Mardhotillah, Atmadian Pratama \\ Department of Agricultural Engineering, Syiah Kuala University, Banda Aceh 23111, Indonesia
}

Corresponding Author Email: darwin_ae@unsyiah.ac.id

https://doi.org/10.18280/ijdne.160608

Received: 29 October 2021

Accepted: 8 December 2021

\section{Keywords:}

anaerobic co-digestion, POME, cow manure, methane, biodegradation

\begin{abstract}
The performance of anaerobic co-digestion of cow manure and POME was evaluated. The anaerobic composting process was carried out by using semi-continuous reactors under the mesophilic condition $\left(35 \pm 1^{\circ} \mathrm{C}\right)$. The addition of POME to the on-going anaerobic composting of cow manure was applied stepwise within a cycle of HRT (20 days). Results showed that the anaerobic co-digestion reactor could produce methane at about six times higher $\left(7.2 \mathrm{~L} \mathrm{CH}_{4}\right)$ than the control reactor $\left(1.3 \mathrm{~L} \mathrm{CH}_{4}\right)$. An increasing of POME loaded to the on-going anaerobic composting cow manure culture (4\% to $64 \%$ ) did not affect $\mathrm{pH}$ of the culture in which $\mathrm{pH}$ was still stable between 7.11 and 7.5. Assessment of biodegradation efficiency revealed that nitrogen removal of the anaerobic co-digestion reactor was six times higher $(21 \%)$ than the nitrogen removal of the control reactor $(3.4 \%)$. This suggested that the anaerobic co-digestion reactor performed sufficiently well in which no organic acid as well as ammonia accumulated in the reactor that could be effective to decompose the organic matters.
\end{abstract}

\section{INTRODUCTION}

The crude palm oil industry has an important role in Indonesia's economy. This is due to the fact that the industry has a significant impact on cutting unemployment rate, providing jobs and incomes, and improving living standards of all people or community involved [1]. As palm oil is considered as a multi-purpose edible vegetable oil, it could give significant prospects for further expansion and development. This occurs as there is an increasing demand of palm oil used as a feedstock for the commercial food and/or oleo-chemical industries including the production of cosmetics, pharmaceuticals, processed foods, soaps, agrochemical products and biodiesel [2, 3].

Palm oil is produced from the extraction of the fruit of the oil palm tree (Elaeis guineensis). The major products obtained from the extraction process of the oil palm fruits are crude palm oil (CPO) and palm kernel oil (PKO) [4]. The production of palm oil normally generates some residues and/or wastes including solid and liquid wastes [5]. The solid residues include oil palm empty fruit bunches oil palm fronds, oil palm trunk and oil palm shell waste while the liquid waste may include palm oil mill effluent (POME) [6, 7]. The unprocessed wastes would generate some environmental problems if they are not controlled and/or managed properly [8]. The practices of direct disposal or burning the solid wastes would generate air pollution and may support to the global warming. This occurs since improper management in terms of processing the wastes may contribute to generate greenhouse gas emissions [9], such as nitrogen oxides (NOx), carbon monoxide (CO), carbon dioxide $\left(\mathrm{CO}_{2}\right)$, sulphur dioxide $\left(\mathrm{SO}_{2}\right)$ and methane $\left(\mathrm{CH}_{4}\right)$.

POME is wastewater produced from palm oil milling processes. Typically, it consists of various kinds of suspended materials [10]. Since POME contains a significant amount of organic materials, the direct disposal of this waste into watercourses would extremely pollute the water resources [11]. This occurs as the oxidation or the decomposition of organic wastes in the water would cause the reduction of the dissolved oxygen and increase the chemical oxygen demand (COD) of the water. Hence, this condition could harm living organisms, and may destroy the water ecosystems.

In order to prevent as well as minimize the risk of environmental pollution caused by the disposal of palm oil wastes, the current study would carry out the treatment of organic wastes derived from the crude palm oil industry. In this present study, the experiment was focused on the treatment of the liquid waste specifically POME. This is because the waste was too acidic, and thereby could pollute not only the watercourses but also the soil and land resources [12]. As POME is rich in organic materials, anaerobic codigestion would be feasible to be applied. This is due to the fact that anaerobic co-digestion process not only could produce liquid compost as a bio-fertilizer but also could generate methane gas as a renewable energy.

The present study aimed to evaluate the co-digestion process of cow manure and POME under the anaerobic and mesophilic conditions. Study by Sidik et al. [13] revealed that POME and cow manure are excellent substrates for biogas production. They found that biogas and its methane content could be increased effectively via anaerobic co-digestion under the mesophilic condition [13]. In this current study, the effects of stepwise loaded POME to the on-going anaerobic digester composting cow manure would be evaluated to find a feasible approach for optimizing the methane production. The effectiveness of biological decomposition would be evaluated through the assessment of biodegradation efficiency including organic removal parameters, methane productivity and 
methane yield as parameters representing a complete process of anaerobic decomposition of organic matters.

\section{MATERIAL AND METHOD}

\subsection{Feed preparation}

The main substrate used for this experiment was cow manure, which was taken from the cow farming at Limpok, sub-district of Darussalam, Banda Aceh, Indonesia. Palm oil mill effluent (POME) used as a co-substrate in this experiment was obtained from the Crude Palm Oil Factory, PT. Agro Sinergi Nusantara PKS Batee Puteh, Teunom, District of Aceh Jaya, Province of Aceh, Indonesia. The collected feedstocks were sieved to remove any contaminants (i.e., woods, metals, plastics, sands and gravels), and stored in the refrigerator at the temperature of $5.0 \pm 0.5$ until they are utilized for the experiments.

\subsection{Digester set-up}

Two identical acrylic digesters were utilized for operating anaerobic composting process. Both digesters were continuously stirred at about $100 \pm 10 \mathrm{rpm}$. Each reactor was equipped with the two sample ports on the top of the reactor, which were used for loading the influent and withdrawing the effluent. The operational temperature set up for running anaerobic composting process was maintained under the mesophilic condition at the temperature of $35 \pm 1{ }^{\circ} \mathrm{C}$ by utilizing thermostatic water bath. To monitor the daily production of methane, gas meters based on the water displacement method were installed and connected to the digesters.

\subsection{Digester operation}

To investigate as well as evaluate the performance of anaerobic co-digestion process, the first digester was used for operating the process of anaerobic co-digestion of POME and cow manure while the second digester was utilized as a control digester, which conducted the composting process of cow manure only. Each digester has a working volume of 4 liter. To avoid the digesters' failure due to organic acid accumulation, the hydraulic retention time (HRT) applied to the anaerobic co-digestion process was 25 days. The loading rate introduced to the anaerobic digesters was $160 \mathrm{~mL} / \mathrm{day}$. To purify methane produced from the digesters, a $500 \mathrm{~mL}$ of 4 Normal $\mathrm{NaOH}$ was filled into a filter flask that was connected to the anaerobic digesters and gas meters. The alkaline solution was used for entrapping gas impurities, such as $\mathrm{CO}_{2}$, $\mathrm{H}_{2} \mathrm{~S}$ generated from the anaerobic digesters. Before starting the experiment, each digester was purged with nitrogen gas for about 3 to 5 minutes in order to get rid of the oxygen traces and ensure the anoxic condition in the digester $[14,15]$.

\subsection{Experimental design and procedures}

Prior to the start of the experiments, the culture in the digester was acclimated with anaerobic as well as mesophilic environment until getting the steady state condition. During this period, there were no $\mathrm{pH}$ adjustment, no substrate added and no effluent withdrawn. The experiment could be started once the culture $\mathrm{pH}$ was stable and close to the neutral level, which was about $7.0 \pm 0.2$. Samples of the influent and/or effluent of each reactor were taken on a daily basis for further analysis. To assure the process of anaerobic digestion could work properly under the continuous operation, $\mathrm{pH}$ of the culture was regularly monitored during the feeding and discharging period. In the process of anaerobic composting, $\mathrm{pH}$ was not controlled, and thereby no acids and/or alkaline were added to the digesters.

As POME was too acidic in which its $\mathrm{pH}$ was lower than 5.0 , the use of this feedstock as a co-substrate was managed as well as applied with the lower composition. In this experiment, the addition of POME to the anaerobic culture was started from $4 \%$ to $64 \%$. This procedure was established to prevent the risk of the digester failure due to acid accumulation, and to evaluate whether the addition of POME to the on-going anaerobic composting of cow manure could enhance methane production as a byproduct of the composting process. The continuous operation of the anaerobic co-digestion process was carried out in one cycle of HRT (25 days). Hence, the composition of POME added to the on-going anaerobic culture was altered after 5 days of incubation. In order to evaluate the digester performance during the addition of POME, no acids and/or alkaline solution was added to the digester.

\subsection{Analytical methods}

The samples of influent as well as effluent taken from the process of anaerobic composting were analyzed for some parameters including $\mathrm{pH}$, total dissolved solids (TDS), total solids (TS), volatile solids (VS), moisture content (MC), total kjedahl nitrogen (TKN), Chemical oxygen demand (COD). To evaluate the physicochemical characteristics of the substrates used for the composting process, samples was taken for the analysis of pH, TDS, TKN, MC, TS, VS, COD and TKN. All measured parameters were analyzed according to the Standard Method of APHA [16].

To evaluate the presence of organic content in the substrate loaded and its effects to the performance of anaerobic digesters, the organic loading rate was measured based on the solid content of the substrates and its flow rate. Biodegradation efficiency of the anaerobic composting process was evaluated by assessing the percentage of volatile solid reduction, COD and TKN removal. The production rates of methane were measured based on the volume (L) of methane produced per day $\left(\mathrm{CH}_{4}\right.$. day $\left.{ }^{-1}\right)$. To evaluate the efficiency of substrate conversion toward the methane production, the yield of methane production was measured, based on the total methane production per mass unit of volatile solids added [17, 18].

\section{RESULTS AND DISCUSSION}

The process of anaerobic co-digestion of cow-manure and POME was carried out under the continuous operation. Under the anoxic condition, the complete decomposition of organic materials could generate methane gas as the main product [19]. The characteristics of substrates used for the anaerobic composting process would determine the organic decomposition rates, methane productivity and methane yield [20]. Hence, evaluation of the physico-chemical characteristics of the substrates used for the process of anaerobic composting would be essential. This is due to the fact that some parameters, such as TS, VS, TKN and COD may identify the strength of organic matters of the substrates 
loaded to the anaerobic digesters. Table 1 summarizes the physical-chemical characteristics of the substrates loaded to the anaerobic digesters.

Results showed that $\mathrm{pH}$ of cow manure was quite well (6.83) for undergoing anaerobic digestion process. This was due to the fact that the $\mathrm{pH}$ was close to the optimum level for anaerobic digestion, which ranged from 6.8 to $7.2[21,22]$. This was quite different from $\mathrm{pH}$ of POME, which was too acidic at around 4.8. The low $\mathrm{pH}$ of POME may completely inhibit the process of anaerobic digestion. Hence, co-digestion of POME with cow manure would be significant to cut the risk of the digester failure due to acid accumulation. As depicted in Table 1, POME has a significant amount of organic materials represented in high concentration of COD (24725 $\mathrm{mg} / \mathrm{L}$ ). This could be prospective to be used as a substrate for anaerobic co-digestion process since one of the main products derived from the process is methane that can be used as renewable energy.

Table 1. Physico-chemical characteristics of the substrates

\begin{tabular}{cccc}
\hline Parameters & Unit & Cow Manure & POME \\
\hline Total solids & $\%$ & 2.2 & 6.701 \\
Volatile solids & $\%$ & 44 & 53.109 \\
Moisture content & $\%$ & 97.8 & 93.299 \\
Total kjedahl nitrogen & $\mathrm{mg} / \mathrm{L}$ & 410 & 524 \\
Chemical oxygen demand & $\mathrm{mg} / \mathrm{L}$ & 9120 & 24725 \\
Total dissolved solids & $\mathrm{mg} / \mathrm{L}$ & 2700 & 3200 \\
Alkalinity & $\mathrm{mg} / \mathrm{L}$ & 2604 & 60.05 \\
$\mathrm{pH}$ & - & 6.83 & 4.78 \\
\hline
\end{tabular}

Results showed that the influent $\mathrm{pH}$ of the co-digestion culture was somewhat acidic in which the $\mathrm{pH}$ was about 6.5 (Table 2). Even if the optimum $\mathrm{pH}$ range for operating anaerobic composting is from 6.8 to 7.2 , the decomposition process in anaerobic composting still could tolerate at a range $\mathrm{pH}$ of 6.5 up to 8.0 [23]. This suggested that the co-digestion culture $\mathrm{pH}$ was still in the tolerable level to undergo the digestion process anaerobically. In terms of organic matters represented in the COD content (Table 2), results showed that the COD concentration of the co-digestion culture was in about of more than two times higher $(20000 \mathrm{mg} / \mathrm{L})$ than the COD of the cow manure alone $(9000 \mathrm{mg} / \mathrm{L})$. High COD concentration in the co-digestion culture was in line with the organic loading rate (OLR) in which its OLR was more than three times higher $\left(1.4 \mathrm{~g}\right.$. VS L ${ }^{-1}$.day $\left.{ }^{-1}\right)$ in comparison to the OLR of the control reactor $\left(0.4\right.$ g.VS L ${ }^{-1} \cdot$ day $\left.^{-1}\right)$.

Besides, the current study revealed that the volatile solid content of the anaerobic co-digestion culture (76\%) was higher than the culture of cow manure alone (44\%). This indicated that the addition of POME to the on-going process of anaerobic digestion could significantly increase the organic content in the culture. High volatile content in the co-digestion culture may suggest that the culture was rich in organic materials [24]. This suggested that POME added to the ongoing anaerobic digestion process could enhance the availability of organic matters in the digester. Organic matter containing culture was highly required by the anaerobic microbes for their growth $[25,26]$, and could potentially be oxidized to form methane as the end-product [27].

In order to evaluate to what extent, the addition of POME to the on-going anaerobic composting of cow manure affecting the performance of the anaerobic digesters, POME added to the digester was altered in every five days. The acclimatization period and/or the lag phase in the anaerobic co-digestion occurred for 24 hours of the early incubation. Results showed that anaerobic co-digestion of cow manure and POME had started to produce methane at the third day of incubation (110 $\mathrm{ml})$ while the control reactor produced no significant amount of methane $(5 \mathrm{ml})$. A significant increase of methane production in the anaerobic co-digestion process occurred from $125 \mathrm{ml}$ (day 5) to $350 \mathrm{ml}$ (day 15). This suggested that the addition of POME stepwise could significantly enhance methane production in comparison to the composting process of cow manure alone.

Table 2. Influent of anaerobic composting process

\begin{tabular}{cccc}
\hline Parameters & Unit & Control & $\begin{array}{c}\text { Co- } \\
\text { digestion }\end{array}$ \\
\hline Total solids & $\%$ & 2.29 & 4.65 \\
Volatile solids & $\%$ & 43.92 & 76 \\
Moisture content & $\%$ & 97.71 & 95.35 \\
Total kjedahl nitrogen & $\mathrm{mg} / \mathrm{L}$ & 414 & 483 \\
Chemical oxygen demand & $\mathrm{mg} / \mathrm{L}$ & 9000 & 20000 \\
Total dissolved solids & $\mathrm{mg} / \mathrm{L}$ & 2710 & 3250 \\
Organic loading rate & g.VS/L.day & 0.402 & 1.414 \\
pH & - & 6.72 & 6.50 \\
\hline
\end{tabular}

The present study revealed that even if the proportion of POME added to the on-going anaerobic digestion of cow manure was continuously increased from $4 \%$ (day 1) to $64 \%$ (day 20), the anaerobic digester still performed stably (Figure 1). This could be seen on the culture $\mathrm{pH}$ during the decomposition process in which the $\mathrm{pH}$ was stable at the level of 7.06. This indicated that the culture $\mathrm{pH}$ was still in the range of an ideal $\mathrm{pH}$ for running anaerobic digestion and/or anaerobic composting process $[23,28]$. The current study was in agreement with the study by Zorpas et al. [29] revealing that the optimum $\mathrm{pH}$ values for the bacterial development on the processing of anaerobic compost production are from 6 to 7.5. This suggested that the addition of a sufficient amount of POME to the on-going anaerobic co-digestion reactor would not inhibit the digestion process. This occurred as the rate of acid production during the acidogenesis could be equal to the rate of acid utilization during the acetogenesis and/or methanogenesis phase. Hence, the balance process would be accomplished for optimizing methane production [30].

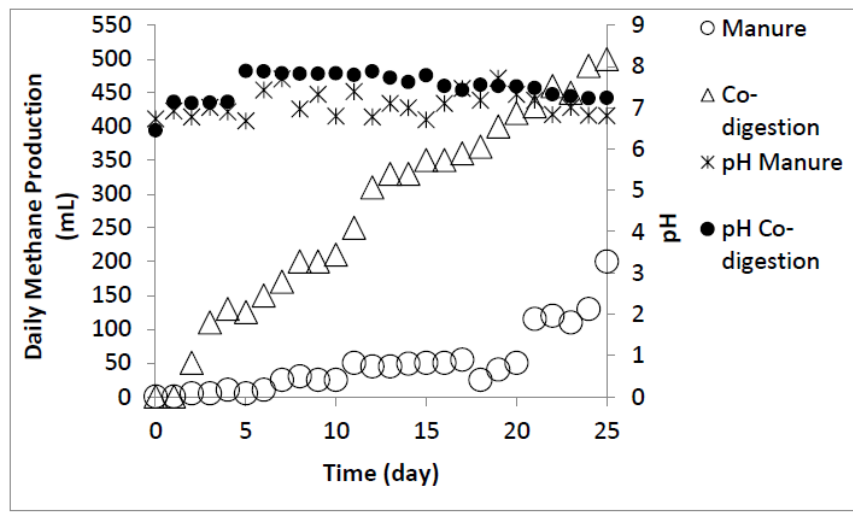

Figure 1. Methane produced per day from anaerobic codigestion of cow manure and POME

Results of the experiment revealed that the maximum production of methane within a cycle of HRT (25 day) was about $500 \mathrm{~mL}$. The total methane production within 20 days of incubation obtained from the anaerobic co-digestion cow- 
manure and POME was about six times higher $\left(7105 \mathrm{~mL} . \mathrm{CH}_{4}\right)$ than the total methane production derived from the composting of cow manure only $(1274 \mathrm{~mL})$. Besides, the current study showed that even if POME was too acidic $(\mathrm{pH}$ 4.8) to be used as the main substrate for anaerobic digestion, it still could contribute to enhance methane production when it is co-digested and/or loaded stepwise into the on-going anaerobic composting culture.

After undergoing the composting process, the results showed that total solids of the control reactor reduced from $2.29 \%$ to $1.87 \%$, which was about 18 percent of the solid reduction. The result was different from the co-digestion reactor, which could reach 52.3 percent reduction in which the solid content in the co-digestion culture reduced from $4.65 \%$ to $2.22 \%$. This suggested that the anaerobic co-digestion culture was rich in biodegradable materials that could be easy to decompose biologically as well as anaerobically. Further, results of the present study revealed that $\mathrm{pH}$ of the effluents of both control reactor (6.82) and co-digestion reactor (7.25) were close to the neutral level (Table 3 ). The results suggested that the effluents or the digested materials obtained from the anaerobic composting process were feasible to be used as a compost and/or soil emulsifier. This was due to the fact that the results were in line with the study revealing that $\mathrm{pH}$ of most finished composts were neutral, which ranged from 6.5 to 7.5 [31].

Table 3. Effluent data of anaerobic composting process

\begin{tabular}{cccc}
\hline Parameters & Unit & Control & Co-digestion \\
\hline Total solids & $\%$ & 1.87 & 2.22 \\
Volatile solids & $\%$ & 23.7 & 51.36 \\
Moisture content & $\%$ & 98.13 & 97.78 \\
Total kjedahl nitrogen & $\mathrm{mg} / \mathrm{L}$ & 400 & 382 \\
Chemical oxygen demand & $\mathrm{mg} / \mathrm{L}$ & 7200 & 14000 \\
Total dissolved solids & $\mathrm{mg} / \mathrm{L}$ & 3430 & 2710 \\
$\mathrm{pH}$ & - & 6.82 & 7.25 \\
\hline
\end{tabular}

Evaluation on the biodegradation efficiency revealed that the addition of POME to the on-going anaerobic composting cow manure could significantly increase methane production in comparison to the anaerobic composting of cow manure alone. As presented in Table 4, the methane productivity in the anaerobic co-digestion cow-manure and POME was almost six times higher $\left(275 \mathrm{~mL} . \mathrm{CH}_{4} \cdot \mathrm{L}^{-1}\right)$ than the composting of cow manure only (49 mL. $\left.\mathrm{CH}_{4} \cdot \mathrm{L}^{-1}\right)$. Results of the experimental study also showed that methane yield of anaerobic codigestion reactor was higher $\left(51 \mathrm{~mL} \mathrm{CH}_{4} \cdot \mathrm{g}^{-1} \mathrm{VS}^{-1}\right)$ than the methane yield of control reactor $\left(32 \mathrm{~mL} \mathrm{CH}_{4} \cdot \mathrm{g}^{-1} \mathrm{VS}^{-1}\right)$. This suggested that the anaerobic co-digestion reactor contained a significant amount of organic matters as a result of POME addition to the reactor.

Table 4. Efficiency of biodegradation

\begin{tabular}{cccc}
\hline Parameters & Unit & Control & $\begin{array}{c}\text { Co- } \\
\text { digestion }\end{array}$ \\
\hline $\begin{array}{c}\text { COD removal } \\
\text { Nitrogen removal } \\
\text { Volatile solids } \\
\text { reduction }\end{array}$ & $\%$ & 20.00 & 30.00 \\
$\begin{array}{c}\text { Total methane } \\
\text { production } \\
\text { Methane } \\
\text { productivity }\end{array}$ & $\begin{array}{c}\mathrm{mL} \mathrm{CH}_{4} / \mathrm{day} \\
\mathrm{mL} \mathrm{CH}_{4} / \mathrm{g}\end{array}$ & 4.38 & 20.91 \\
Methane yield & 31.67 & 66.66 \\
\hline
\end{tabular}

The assessment of biodegradation efficiency also found that the anaerobic co-digestion reactor had a high rate of organic removal, which was represented in the high percentage of COD removal (30\%) in comparison to the removal rate of the anaerobic composting cow manure alone (20\%). Besides, the high rate of organic removal during the composting process could also occur in the nitrogen content of the culture. The current study showed that the anaerobic co-digestion reactor effectively reduced the nitrogen content of the culture, which was more than six times higher $(21 \%)$ than the nitrogen removal of the control reactor $(3.4 \%)$. High organic removal rate of the anaerobic co-digestion reactor could be attributed to its neutral $\mathrm{pH}$ value (7.2) in which the $\mathrm{pH}$ could be effective for biodegradation and/or decomposition processes of the organic materials. The current results were in agreement with some studies revealing that $\mathrm{pH}$ was a key factor to succeed the biodegradation process $[32,33]$. They found that most of the microbes would evolve effectively in the $\mathrm{pH}$ range of 6 to 8 with the optimal level of 6.5-7.2 and extreme in $\mathrm{pH}$ (too acidic and/or too basic) may slow down the capability of the microbial population for degrading the organic materials.

In this present study, the decomposition process of organic solid matters still performed sufficiently well although the addition of POME to the on-going anaerobic composting reactor was gradually increased. This could be related to the percentage of volatile solid reduction, which still could accomplish above sixty percent $(67 \%)$. The result is somewhat different from some studies revealing that volatile solid reduction could be low when the loading of organic materials was increased $[34,35]$. The low volatile solid reduction could be attributed to the organic acids accumulated in the digester. The acids build-up may be resulted by the oxidation of organic acids in the acidification stage that may lead to lower $\mathrm{pH}$ of the anaerobic culture $[30,36]$. The acidic condition may completely restrict the conversion process of organic materials during the hydrolysis phase, and also inhibit the oxidation of organic acids during the acetogenesis and/or methanogensis stage to form methane [35].

\section{CONCLUSIONS}

The present study showed that the addition of POME as cosubstrate to the on-going anaerobic composting of cow manure produced more than five times of methane productivity $(275$ $\mathrm{mL} \mathrm{CH}_{4} /$ day) in comparison to the anaerobic composting of cow manure alone $\left(49 \mathrm{~mL} \mathrm{CH}_{4} /\right.$ day). The results showed that the $\mathrm{pH}$ of the anaerobic co-digestion culture was stable and close to the neutral level (7.1-7.25) even if the addition of POME as a source of organic matters was increased. Assessment of biodegradation efficiency parameters revealed that organic removals in the anaerobic co-digestion reactor were higher in comparison to the anaerobic composting of cow manure only. The results of the study suggested that the addition of POME stepwise to the on-going anaerobic composting culture did not affect the performance of the anaerobic digester, and may significantly enhance methane production.

\section{ACKNOWLEDGMENT}

The authors are pleased to acknowledge Universitas Syiah Kuala, Banda Aceh, Indonesia for the financial support 
through the program scheme of product-based community service (grant number: 8/UN11.2.1/PN.01.01/PNBP/2021) coordinated by the Institute for Research and Community Services, USK.

\section{REFERENCES}

[1] Barlow, C., Zen, Z., Gondowarsito, R. (2003). The Indonesian oil palm industry. Oil Palm Industry Economic Journal, 3(1): 8-15.

[2] Basiron, Y. (2002). Palm oil and its global supply and demand prospects. Oil Palm Industry Economic Journal, 2(1): 1-10.

[3] Hayyan, M., Mjalli, F.S., Hashim, M.A., AlNashef, I.M. (2010). A novel technique for separating glycerine from palm oil-based biodiesel using ionic liquids. Fuel Processing Technology, 91(1): 116-120. https://doi.org/10.1016/j.fuproc.2009.09.002

[4] Hashim, K., Tahiruddin, S., Asis, A.J. (2012). Palm and palm kernel oil production and processing in Malaysia and Indonesia. In Palm Oil, pp. 235-250. https://doi.org/10.1016/B978-0-9818936-9-3.50011-3

[5] Embrandiri, A., Ibrahim, M.H., Singh, R.P. (2013). Palm oil mill wastes utilization; sustainability in the Malaysian context. International Journal of Scientific and Research Publication, 24(3): 63-68.

[6] Chavalparit, O., Rulkens, W.H., Mol, A.P.J., Khaodhair, S. (2006). Options for environmental sustainability of the crude palm oil industry in Thailand through enhancement of industrial ecosystems. Environment, Development $\begin{array}{lll}\text { and } & \text { Sustainability, } & \text { 271-287. }\end{array}$ https://doi.org/10.1007/s10668-005-9018-z

[7] Sridhar, M.K., AdeOluwa, O.O. (2009). Palm oil industry residues. In Biotechnology for Agro-Industrial Residues Utilisation, Springer, Dordrecht, 341-355. https://doi.org/10.1007/978-1-4020-9942-7_18

[8] Rupani, P.F., Singh, R.P., Ibrahim, M.H., Esa, N. (2010). Review of current palm oil mill effluent (POME) treatment methods: vermicomposting as a sustainable practice. World Applied Sciences Journal, 11(1): 70-81.

[9] Stichnothe, H., Schuchardt, F. (2011). Life cycle assessment of two palm oil production systems. Biomass and Bioenergy, 35(9): 3976-3984. https://doi.org/10.1016/j.biombioe.2011.06.001

[10] Poh, P.E., Yong, W.J., Chong, M.F. (2010). Palm oil mill effluent (POME) characteristic in high crop season and the applicability of high-rate anaerobic bioreactors for the treatment of POME. Industrial \& Engineering Chemistry Research, 49(22): 11732-11740. https://doi.org/10.1021/ie101486w

[11] Ahmad, A.L., Ismail, S., Bhatia, S. (2003). Water recycling from palm oil mill effluent (POME) using membrane technology. Desalination, 157(1-3): 87-95. https://doi.org/10.1016/S0011-9164(03)00387-4

[12] Okwute, L.O., Isu, N.R. (2007). The environmental impact of palm oil mill effluent (pome) on some physicochemical parameters and total aerobic bioload of soil at a dump site in Anyigba, Kogi State, Nigeria. African Journal of Agricultural Research, 2(12): 656-662.

[13] Sidik, U.H., Razali, F.B., Alwi, S.R.W., Maigari, F. (2013). Biogas production through co-digestion of palm oil mill effluent with cow manure. Nigerian Journal of Basic and Applied Sciences, 21(1): 79-84. https://doi.org/10.4314/njbas.v21i1.12

[14] Gontupil, J., Darwin, Liu, Z., Cheng, J.J., Chen, H. (2012). Anaerobic co-digestion of swine manure and corn stover for biogas production. Annual International Meeting Conference, American Society of Agricultural and Biological Engineers, July 29-August 1, 2012, Dallas, U.S.A.

[15] Darwin, Cheng, J.J., Liu, Z., Gontupil, J. (2016). Anaerobic co-digestion of cocoa husk with digested swine manure: evaluation of biodegradation efficiency in methane productivity. Agricultural Engineering International: The CIGR Journal, 18: 147-156.

[16] Rice, E.W., Baird, R.B., Eaton, A.D. (2017). Standard Methods for the Examination of Water and Wastewater $23^{\text {rd }}$ Edition. American Public Health Association (APHA), Washington, D.C., U.S.A.

[17] Chandra, R., Takeuchi, H., Hasegawa, T. (2012). Hydrothermal pretreatment of rice straw biomass: a potential and promising method for enhanced methane production. Applied Energy, 94: 129-140. https://doi.org/10.1016/j.apenergy.2012.01.027

[18] Darwin Fazil, A., Ilham, M., Sarbaini, Purwanto, S. (2017). Kinetics on anaerobic co-digestion of bagasse and digested cow manure with short hydraulic retention time. Research in Agricultural Engineering Journal, 63: 121-127. https://doi.org/10.17221/18/2016-RAE

[19] Darwin, Purwanto, S., Rinaldi, R. (2019). Removal of organic pollutants from Tofu-processing wastewater through anaerobic treatment process with short hydraulic retention time. Environmental Research, Engineering and Management, 75(1): 34-42. https://doi.org/10.5755/j01.erem.75.1.21532

[20] Darwin, Ilham, M., Fazil, A. (2018). Performance and kinetic study of the anaerobic co-digestion of cocoa husk and digested cow manure with high organic loading rate. INMATEH-Agricultural Engineering, 55(2): 131-140.

[21] Brummeler, E.T., Pol, L.W.H., Dolfing, J., Lettinga, G., Zehnder, A.J. (1985). Methanogenesis in an upflow anaerobic sludge blanket reactor at $\mathrm{pH} 6$ on an acetatepropionate mixture. Applied and Environmental Microbiology, 49(6): 1472-1477. https://doi.org/10.1128/aem.49.6.1472-1477.1985

[22] Wu, B. (2012). Integration of mixing, heat transfer, and biochemical reaction kinetics in anaerobic methane fermentation. Biotechnology and Bioengineering, 109(11): 2864-2874. https://doi.org/10.1002/bit.24551

[23] Cioabla, A.E., Ionel, I., Dumitrel, G.A., Popescu, F. (2012). Comparative study on factors affecting anaerobic digestion of agricultural vegetal residues. Biotechnology for Biofuels, 5(1): 1-9. https://doi.org/10.1186/17546834-5-39

[24] Orhorhoro, E.K., Ebunilo, P.O., Sadjere, E.G. (2017). Experimental determination of effect of total solid (TS) and volatile solid (VS) on biogas yield. American Journal of Modern Energy, 3(6): 131-135. https://doi.org/10.11648/j.ajme.20170306.13

[25] Franco-Otero, V.G., Soler-Rovira, P., Hernández, D., López-de-Sá, E.G., Plaza, C. (2012). Short-term effects of organic municipal wastes on wheat yield, microbial biomass, microbial activity, and chemical properties of soil. Biology and Fertility of Soils, 48(2): 205-216. https://doi.org/10.1007/s00374-011-0620-y

[26] Darwin, Blignaut, D. (2019). Alkaline treatment for preventing acidosis in the rumen culture fermenting 
carbohydrates: An experimental study in vitro. J. Adv. Vet. Animal Res., 6(1): 100-107. https://dx.doi.org/10.5455\%2Fjavar.2019.f319

[27] Khosa, M.K., Sidhu, B.S., Benbi, D.K. (2010). Effect of organic materials and rice cultivars on methane emission from rice field. Journal of Environmental Biology, 31(3): 281-285.

[28] Darwin, Pratama, A., Mardhotillah. (2021). Organic waste conversion via continuous anaerobic co-digestion of oil palm empty fruit bunches and cow manure: evaluation of feeding regime on methane production. Acta Technologica Agriculturae, 24(1): 8-13. http://dx.doi.org/10.2478/ata-2021-0002

[29] Zorpas, A.A., Arapoglou, D., Panagiotis, K. (2003). Waste paper and clinoptilolite as a bulking material with dewatered anaerobically stabilized primary sewage sludge (DASPSS) for compost production. Waste Management, 23(1): 27-35. https://doi.org/10.1016/s0956-053x(02)00042-9

[30] Darwin, Cord-Ruwisch, R. (2019). Thermodynamics of anaerobic digestion: mechanism of suppression on biogas production during acidogenesis. INMATEHAgricultural Engineering, 57(1): 287-301.

[31] Chen, L., de Haro Marti, M., Moore, A., Falen, C. (2011). The composting process. Dairy Manure Compost Production and Use in Idaho, 2: 513-532.
[32] Leahy, J.G., Colwell, R.R. (1990). Microbial degradation of hydrocarbons in the environment. Microbiology and Molecular Biology Reviews, 54(3): 305-315.

[33] Darwin, Charles, W., Cord-Ruwisch, R. (2019). Anaerobic acidification of sugar-containing wastewater for biotechnological production of organic acids and ethanol. Environmental Technology, 40(25): 3276-3286. https://doi.org/10.1080/09593330.2018.1468489

[34] Nagao, N., Tajima, N., Kawai, M., Niwa, C., Kurosawa, N., Matsuyama, T., Yusoff, F.M., Toda, T. (2012). Maximum organic loading rate for the single-stage wet anaerobic digestion of food waste. Bioresource Technology, 118: 210-218. https://doi.org/10.1016/j.biortech.2012.05.045

[35] Gou, C., Yang, Z., Huang, J., Wang, H., Xu, H., Wang, L. (2014). Effects of temperature and organic loading rate on the performance and microbial community of anaerobic co-digestion of waste activated sludge and food waste. Chemosphere, 105: 146-151. https://doi.org/10.1016/j.chemosphere.2014.01.018

[36] Noutsopoulos, C., Mamais, D., Antoniou, K., Avramides, C., Oikonomopoulos, P., Fountoulakis, I. (2013). Anaerobic co-digestion of grease sludge and sewage sludge: The effect of organic loading and grease sludge content. Bioresource Technology, 131: 452-459. http://dx.doi.org/10.1016/j.biortech.2012.12.193 